F. A. Hohorst

September 1994

\title{
Westinghouse Idaho
}

PREPARED FOR THE

DEPARTMENT OF ENERGY IDAHO OPERATIONS OFFICE

UNDER CONTRACT DE-AC07-84ID12435 


\section{DISCLAIMER}

This report was prepared as an account of work sponsored by an agency of the United States Government. Neither the United States Government nor any agency thereof, nor any of their employees, make any warranty, express or implied, or assumes any legal liability or responsibility for the accuracy, completeness, or usefulness of any information, apparatus, product, or process disclosed, or represents that its use would not infringe privately owned rights. Reference herein to any specific commercial product, process, or service by trade name, trademark, manufacturer, or otherwise does not necessarily constitute or imply its endorsement, recommendation, or favoring by the United States Government or any agency thereof. The views and opinions of authors expressed herein do not necessarily state or reflect those of the United States Government or any agency thereof. 


\section{DISCLAIMER}

Portions of this document may be illegible in electronic image products. Images are produced from the best available original document. 


\section{GENERATION OF GASEOUS TRITIUM STANDARDS}

Frederick A. Hohorst

Introduction

The determination of aqueous and non-aqueous tritium in gaseous samples is one type of determination often requested of radioanalytical laboratories. This determination can be made by introducing the sample as a gas into a sampling train containing two silica gel beds separated by a catalytic oxidizer bed. The first bed traps tritiated water. The sample then passes into and through the oxidizer bed where non-aqueous tritium containing species are oxidized to water and other products of combustion. The second silica gel bed then traps the newly formed tritiated water. Subsequently, silica gel is removed to plastic bottles, deionized water is added, and the mixture is permitted to equilibrate. The tritium content of the equilibrium mixture is then determined by conventional liquid scintillation counting (LSC).

Aqueous tritium reference materials are available from NIST and from commercial suppliers which maintain traceability to NIST. These aqueous reference materials can be used to readily evaluate the efficiency and operation of the first part of such combustion trains. However, gaseous materials containing low levels of tritium are not routinely available as SRMs from NIST. This deficiency impairs the ability of the analyst to evaluate a complete experimental setup.

Reduction of water to diatomic hydrogen can be accomplished using zinc on alumina at $500^{\circ} \mathrm{C}$. [1] There are several drawbacks to this approach including the high temperature and the experimental complexity. 
For many years, the moisture content of inert, gaseous samples has been determined using monitors which quantitatively electrolyze the moisture present after that moisture has been absorbed by phosphorous pentoxide or other absorbents.[2] The electrochemical reaction is quantitative and definitive, and the energy consumed during electrolysis forms the basis of the continuous display of the moisture present. This report discusses the experimental evaluation of such a monitor as the basis for a technique for conversion of small quantities of SRMs of tritiated water $\left({ }^{3} \mathrm{HOH}\right)$ into gaseous tritium standards $\left({ }^{3} \mathrm{HH}\right)$.

\section{Experimental}

All reagents used were analytical grade except where noted. Tritiated water was NBS SRM $4927 \mathrm{~B}$ with a certified activity of $6.099 \times 10^{5} \mathrm{~s}^{-1} \mathrm{~g}^{-1} \pm 0.63 \%$ on september 3,1978 . LSC was carried out using Ecolume (Packard Instrument Co.), a commercial scintillation cocktail. Nitrogen carrier gas was "building nitrogen" taken off a liquid nitrogen storage tank; its typical moisture content without the auxiliary drier was $\leq 4$ ppm. A nitrogen - 20.51\% oxygen - $2.40 \%$ hydrogen carrier mixture was prepared in-house using stock gases and calibrated pressure gauges.

The schematic of the experimental system is shown in Figure 1: The sample inlet system was constructed using $1 / 8$ inch stainless steel tubing, Nupro Model SS-2F-0.5 $\frac{1}{2}$ micron stainless steel filters, and a whitey Model SS-43Y HH FS 2 ball valve. The ball pattern in the valve was a cross in which flow did not mix with the flow at right angles to it. Lengths of 316 stainless steel capillary tubing (T1 \& T2, 0.010 and 0.020 inch dia., respectively) were chosen so that at a total flow of $94.6 \mathrm{sccm}$, $3.24 \pm 0.02 \%$ of the flow went through TI. The moisture monitor (MM) used in this work was an AMETEK Model 303; factory 


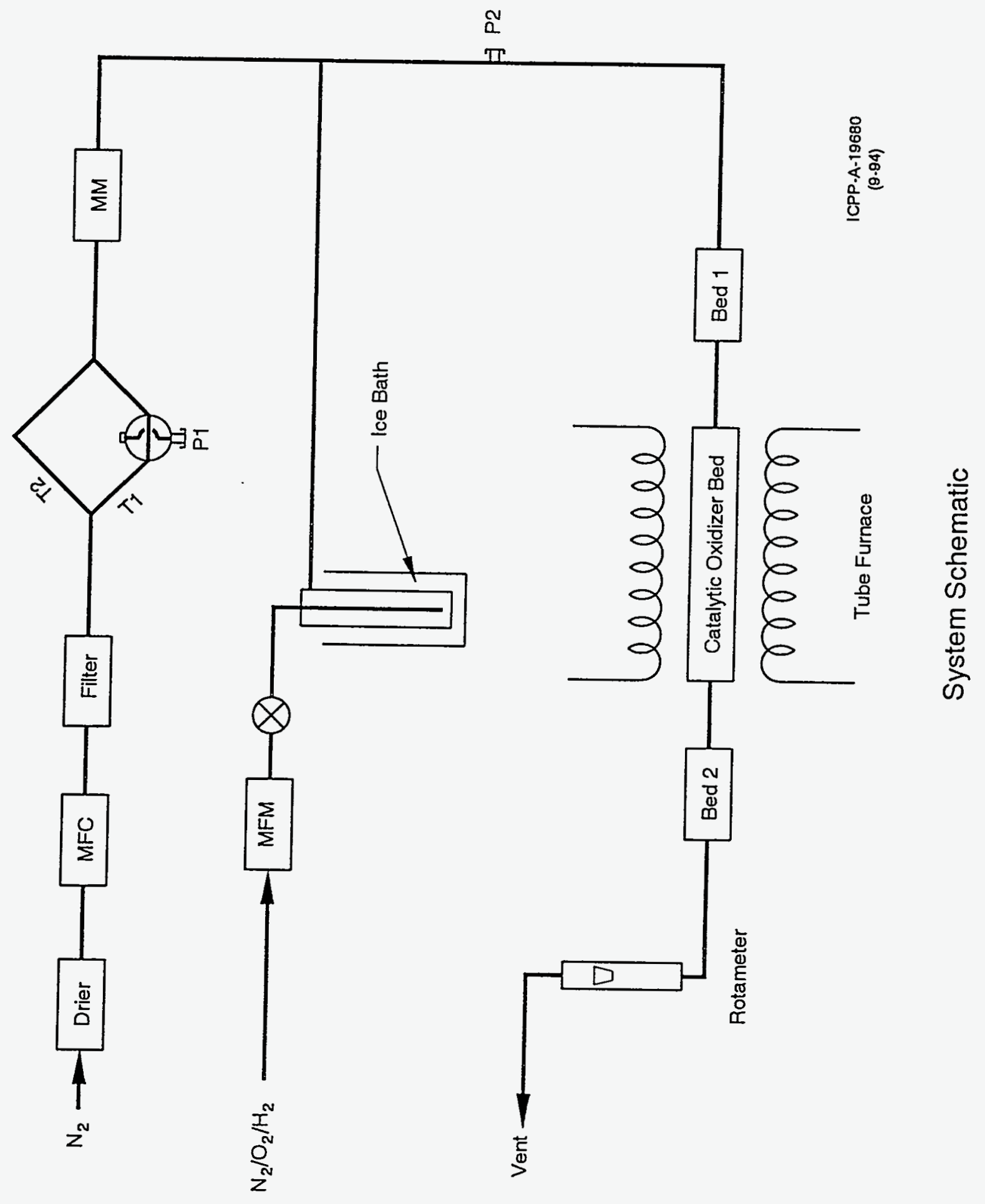

Figure 1 
calibration was for a sample flow of $100 \mathrm{~mL} / \mathrm{min}$ at 1 atm and $60^{\circ} \mathrm{F}(94.6 \mathrm{sccm})$. The unit was used as received except that the flow controller on the outlet was bypassed. Commercial mass flowmeters or mass flow controllers (MFM \& MFC) were utilized as needed. The ice bath was constructed of a glass impinger; ice was placed inside the impinger and the upper walls carefully wiped down before it was reassembled and placed in an insulating Dewar flask containing crushed ice. Injection ports (P1 \& P2) were "tee"s fitted with GC septa. A rotameter was used to verify the presence of flow exiting the system.

[NOTE: Mention of a specific brand of product is for descriptive purposes only. It is not and endorsement by this contractor and is not intended to preclude the existence of equivalent items.]

\section{Results}

The schematic of the system is shown in Figure 1. In order to generate ${ }^{3} \mathrm{HH}$, a small quantity of the ${ }^{3} \mathrm{HOH}$ SRM 10.001 to 0.010 $\mathrm{mL}$ ) was injected into port $\mathrm{P} 1$. Turning the ball valve $90^{\circ}$ placed the aqueous drop in the gas stream with a very small flow of nitrogen passing over it. This flow mixed with the larger flow coming through $\mathrm{T} 2$. The resulting dilution kept the concentration of water high enough to ensure complete electrolysis within several hours but not so high a concentration as to saturate the electrolytic cell in the moisture monitor.

Electrolysis served two purposes: 1) It converted the water to hydrogen, the desired analyte, and 2) It measured accurately just how much water had been injected.

The flow from the electrolytic cell of the moisture monitor was combined with a flow of carrier gas $(20.51 \%$ oxygen $-2.40 \%$ 
hydrogen in nitrogen) which had been saturated with water vapor at $0^{\circ} \mathrm{C}$. This carrier mixture was used to facilitate the trapping of the species by providing a definite mass of material (i.e., more than just "tracer" levels).

A typical output of the system is shown in Figure 2. Sample introduction began at $6 \mathrm{~min}$; monitor response increased sharply within 20 seconds. Electrolysis of $0.005 \mathrm{~mL}$ of the SRM gave a relatively steady generation of ${ }^{3} \mathrm{HH}$ over the course of 80 minutes following introduction at a concentration of 600 to 700 ppm by volume. In the 10 minutes which followed, all liquid was evaporated and the vapors swept from the inlet system. Subsequent heating of the exposed portions of the system with a heat lamp did not release any additional moisture--the baseline remained unchanged.

Upon termination of the run, the silica gel beds were removed, equilibrated with DI water, and analyzed for tritium by ISC using conventional techiniques.

The results of several runs are reported in Table 1. Electrical or graphical integration of the recorder response was based on constant, measured flow through the electrolytic cell. Standards ranging from 1.69 to $4.51 \mathrm{mg}$ were injected and their behavior followed. This approach overcame the problems associated with the injection of small quantities of liquids with common GC syringes.

\section{Conclusions}

A moisture monitor such as that described can successfully be used to electrolyze tritiated water thereby generating gaseous ${ }^{3} \mathrm{HH}$ in the carrier gas being used. Either physical or electronic integration of the area under the recorder tracing of the moisture monitor gives an accurate measure of the 


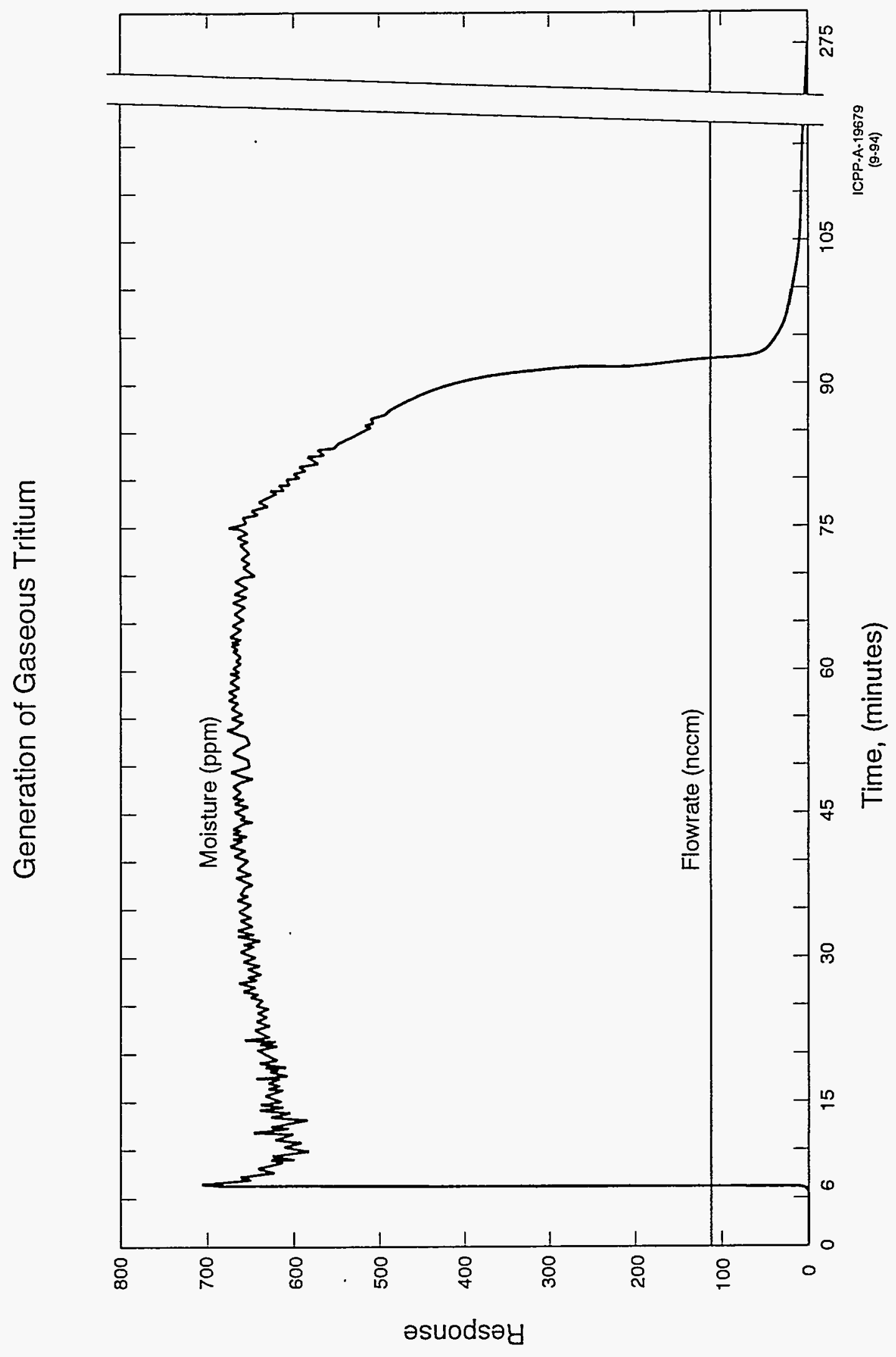

Figure 2 
TABLE 1

Generation of Gaseous Tritium Standards

\begin{tabular}{|c|c|c|c|c|c|c|c|c|c|c|c|}
\hline \multirow{3}{*}{$\begin{array}{c}\text { Run } \\
1\end{array}$} & \multicolumn{2}{|c|}{${ }^{3} \mathrm{HH}$ Water ${ }^{\mathrm{a}}$} & \multirow{3}{*}{$\begin{array}{c}{ }^{3} \mathrm{HOH} \text { Water }{ }^{b} \\
\text { None }\end{array}$} & \multirow{2}{*}{\multicolumn{2}{|c|}{$\begin{array}{l}\text { Flowrates } \\
\frac{{ }^{3} \mathrm{HH}}{(\mathrm{sccm})} \frac{{ }^{3} \mathrm{HOH}}{}\end{array}$}} & \multirow{3}{*}{$\begin{array}{l}\operatorname{Max}^{c} \\
\mathrm{H}_{2} \\
\text { (ppm) } \\
667\end{array}$} & \multirow{2}{*}{\multicolumn{2}{|c|}{$\frac{\text { Duration }}{\frac{\text { Gen }^{\mathrm{c}}}{\text { (min) }}}$}} & \multicolumn{2}{|c|}{ Total Activity } & \multirow{3}{*}{$\begin{array}{c}\text { Recovery } \\
\frac{(\%)}{100.7}\end{array}$} \\
\hline & $(\mu \mathrm{L})$ & $(m g)$ & & & & & & & \multirow{2}{*}{$\begin{array}{l}\frac{\mathrm{H} 2 \mathrm{Bed}}{(\mathrm{d} / \mathrm{min})} \\
4.94 \mathrm{E} 4\end{array}$} & \multirow{2}{*}{$\begin{array}{l}\frac{\mathrm{H} 2 \mathrm{O} \mathrm{Bed}}{(\mathrm{d} / \mathrm{min})} \\
5.04 \mathrm{E} 3\end{array}$} & \\
\hline & 3 & $3.20^{f}$ & & 101.5 & 46 & & 80 & 500 & & & \\
\hline 2 & 5 & $4.36^{f}$ & None & 101.5 & 92 & 694 & 170 & 350 & $7.69 \mathrm{E} 4$ & $4.61 \mathrm{E3}$ & 110.7 \\
\hline 3 & 1.5 & $1.69^{f}$ & 1.5 & 101.5 & 92 & 612 & 50 & 260 & $2.20 \mathrm{E} 4$ & $3.29 \mathrm{E} 4$ & 101.9 \\
\hline 4 & 3.6 & $4.51^{g}$ & 3.7 & 101.5 & 91 & 701 & 90 & 300 & $5.29 \mathrm{E} 4$ & $7.51 \mathrm{E} 4$ & 92.3 \\
\hline
\end{tabular}

a ${ }^{3} \mathrm{HH}$ water is based on syringe reading $(\mu \mathrm{L})$ or moisture monitor response $(\mathrm{mg})$.

b ${ }^{3} \mathrm{HOH}$ water is based on syringe reading $(\mu \mathrm{L})$ only.

c Maximum hydrogen generated in nitrogen for later combination with carrier gas mixture.

d Approximate duration of generation of ${ }^{3} \mathrm{HH}$.

e Approximate total duration of flow through the system.

$f$ Electrical integration of moisture monitor response.

$g$ Mechanical integration of moisture monitor response. 
quantity of water so electrolyzed. Recoveries averaged $101.4 \pm 7.5 \%$

In Runs 1 and 2 , no ${ }^{3} \mathrm{HoH}$ was injected into port $\mathrm{P} 2$ to be trapped as that specie without being electrolyzed. The fact that some tritium is observed in Bed 1 under these conditions indicates that either 1) electrolysis is incomplete, 2) ${ }^{3} \mathrm{HH}$ recombines with $\mathrm{O}_{2}$ prior to reaching Bed 1 or 3 ) ${ }^{3} \mathrm{HH}$ and $\mathrm{O}_{2}$ react on Bed 1 and remain there, or a combination of these effects, under these experiments conditions. Manufacturer's data states that electrolysis consumes $99.9 \%$ of the gaseous water in the range of 1.0 to $1000 \mathrm{ppm}$. Recombination of hydrogen and oxygen has been reported. [3]

At first glance, this effect seems detrimental to operation of the unit for its intended purpose. On further reflection however, this condition can mimic the behavior of real ${ }^{3} \mathrm{HH}$ samples collected in air thus giving the analyst a very realistic evaluation of the experimental setups which are under evaluation.

\section{References}

1. W. R. Miller, E. E. Hughes, and B. M. Coursey, Development of a Stable Tritium (HT) Generation System for Testing Atmospheric HT Monitors, Nucl. Inst. Meth. Phys., 1990, A286, 334 .

2. Michael Czuha, Jr., Electrolytic Films, U. S. Patent No. 3,014,858, December 26, 1961.

3. Instruction Manual, 303 Moisture Monitor, AMETEK (Newark, DE), January, 1993. 